\title{
JOSÉ ANTONIO PÉREZ BOWIE: EL PROFESOR TRANQUILO ${ }^{1}$
}

\author{
Antonio J. GIL GONZÁLEZ \\ Universidade de Santiago de Compostela \\ ajgil@usc.es \\ Javier SÁNCHEZ ZAPATERO \\ Universidad de Salamanca \\ zapa@usal.es
}

$\mathrm{U}$ na de las más bellas tradiciones universitarias es aquella por la que la jubilación de un profesor se celebra con la edición de un volumen colectivo que, a modo de homenaje, cuenta con la participación de algunos de los colegas que le han acompañado a lo largo de su trayectoria científica. Más allá de suponer una muestra de una determinada área de conocimiento, al aglutinar trabajos e investigaciones de algunos de sus principales representantes, este tipo de publicaciones constituyen, por encima de todo, un testimonio de admiración y agradecimiento hacia el legado intelectual y humano dejado por aquellos que terminan su ciclo profesional. Así sucede en este monográfico de la revista Tropelías, dedicado íntegramente a la figura del profesor José Antonio Pérez Bowie, cuya jubilación el 30 de septiembre de 2017 puso fin a una influyente y brillante carrera académica como profesor e investigador de Teoría de la literatura y Literatura comparada: los textos que lo integran no solo evidencian la influencia que sus trabajos han tenido en otros colegas, sino también y sobre todo el respeto con el que su figura y su obra siempre han sido vistas en el ámbito universitario.

De José Antonio Pérez Bowie se podrían decir muchas cosas, pero probablemente las más importantes no figuren en el recuento de sus innumerables logros curriculares, entre los que destacan la coordinación de cinco Proyectos de Investigación del Plan Nacional consecutivos, la creación y

\footnotetext{
${ }^{1}$ Este trabajo forma parte de los proyectos de investigación coordinados «Transescritura, transmedialidad, transficcionalidad: Relaciones contemporáneas entre literatura, cine y nuevos medios II» (FF2014-55958-C2-1-P) —cuyo Investigador Principal fue hasta otoño de 2017 José Antonio Pérez Bowie- e «Intermedialidad, adaptación y transmedialidad en el cómic, el videojuego y los nuevos medios» (FFI2014- 55958-C2-2-P), financiados por el Ministerio de Economía y Competitividad.
} 
dirección del GELYC (Grupo de Estudios de Literatura y Cine), la publicación de más de una centena de artículos de investigación en revistas y monografías científicas, la autoría de alrededor de una veintena de libros, la dirección de decenas de tesis doctorales, la presencia como conferenciante y profesor invitado en innumerables universidades y centros de investigación nacionales e internacionales o, por encima de todo, los más de cuarenta años que ha impartido ininterrumpidamente sus clases en la Universidad de Salamanca, que culminaron en la obtención de la cátedra de Teoría de la literatura y Literatura comparada en 2007, desempeñada con anterioridad por ilustres maestros de la filología española como Fernando Lázaro Carreter o Ricardo Senabre.

Pero como sucede en la literatura y en el arte en general, el «qué» no suele importar tanto como el «cómo», por lo que, a la hora de hacer balance de su trayectoria, resulta mucho más relevante aludir a sus valores éticos y humanos que a la mera acumulación de sus méritos. Es cierto que en el profesor Pérez Bowie encontramos a un docente capaz de hipnotizar a un auditorio sin más ayuda que su pausada cadencia al hablar, su fina ironía y su habilidad para estructurar el discurso — sin olvidar esa postura tan peculiar, sentado con el brazo colocado sobre el respaldo del asiento, o esa muletilla de «¿están ustedes cansados?» con la que sistemáticamente apela a su auditorio-, o a un investigador ecléctico y brillante que supo pasar de la semántica generativa en la que se inscribió su tesis doctoral al estudio de la teoría de la adaptación y las relaciones intermediales que marcan la actualidad de la teoría literaria y el comparatismo; pero es mucho más cierto que, por encima de todo, en su persona se dan cita la bonhomía, la humanidad, la sencillez, la humildad y la generosidad del discípulo, el maestro, el compañero, el profesor y el amigo. Por todo lo cual, unido a su amor por el cine y su gusto por utilizar o modificar los títulos de películas en sus trabajos, hemos optado por el de «El profesor tranquilo» como título de este modesto y sincero homenaje.

Confiamos que se nos disculpará que sea a esta dimensión personal y humana de su figura, antes que a la de su perfil intelectual y académico, a la que dediquemos inicialmente una breve semblanza.

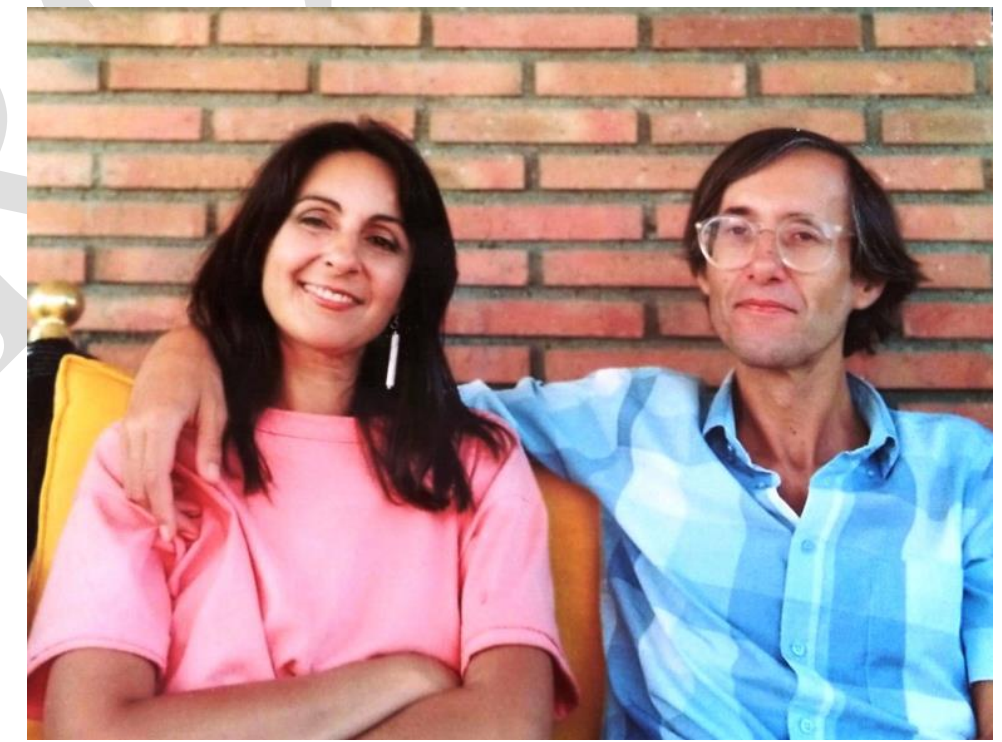

José Antonio Pérez Bowie, con Ana María Royo, en 1989 
José Antonio Pérez Bowie nació en 1947 en Alosno, provincia de Huelva, villa cuyo Centro de Educación Secundaria para adultos lleva hoy su nombre. Hijo del comerciante local Rodrigo Pérez y de Juana Bowie, su característico apellido materno se debe a su bisabuelo William Bowie Guthrie, ingeniero escocés llegado a las Minas de Tarsi a finales del siglo XIX, y que se convertirá en emblema tanto de un patronímico recurrente de Guillermos y Guillerminas en la familia, como de un cosmopolitismo que se prolonga en la actualidad de sus nietos hacia otras latitudes mucho más distantes aún. Al sustrato familiar de esa cierta educación inglesa se unieron el carácter de lector vocacional de su padre y el empeño de su madre en que se dedicase al estudio, todo lo cual terminará llevándolo al camino de las letras, en detrimento de otras pasiones más privadas, como la taurina, que aunque quedará reservada a la fabulación lúdica ante sus conocidos o amigos más crédulos - en la cual, encarnando al banderillero «El niño del Conquero», se hará a sí mismo protagonista de un melodrama con la cupletista Esmeralda, que bien podría haber salido del guión de una de tantas de las películas del catálogo del cine español de la época a cuyo estudio se dedicaba- le valdrá en cierta ocasión que una de sus conferencias universitarias en la ciudad de Zaragoza apareciese reseñada en la sección taurina del periódico local.

Tras finalizar sus estudios primarios, a los once años se trasladó a Huelva a cursar el Bachillerato, primero interno en el colegio de los Maristas - que no conseguirán inculcarle la afición futbolística pero sí consolidar la literaria, como ilustra la imagen del anecdotario familiar que lo muestra leyendo a escondidas en un rincón del estadio al que le llevaban a ver los partidos dominicales del Recreativoy después en el Instituto de la localidad. Inició sus estudios superiores de Filosofía y Letras en Sevilla, para poco después trasladarse en 1967 a la ciudad de Salamanca, en cuya Universidad se licenció en Filología Románica en 1970 y se doctoró en Filosofía y Letras en 1975; ciudad y universidad a las que permanecerá ya unido siempre hasta el presente — con la única excepción del curso 1970-1971, en el que ejerció como profesor de enseñanza media en Castellón tras su licenciatura-, primero como profesor ayudante de Fernando Lázaro Carreter, profesor adjunto, encargado de curso, agregado e incluso catedrático interino, hasta convertirse en 1987 en profesor titular de Teoría de la literatura y, desde 2007, en catedrático de la misma área de conocimiento —entretanto redenominada como Teoría de la literatura y literatura comparada-, sucediendo a Ricardo Senabre.

Ya afincado en Salamanca, se casa en 1971 con Ana María Royo, con quien escribirá la mejor de sus obras: la feliz y ya numerosa familia que, además de sus hijos Guillermo, Darío y Victoria, le ha dado hasta el momento a sus nietos Lara, Alba, Valentina y Leo. 


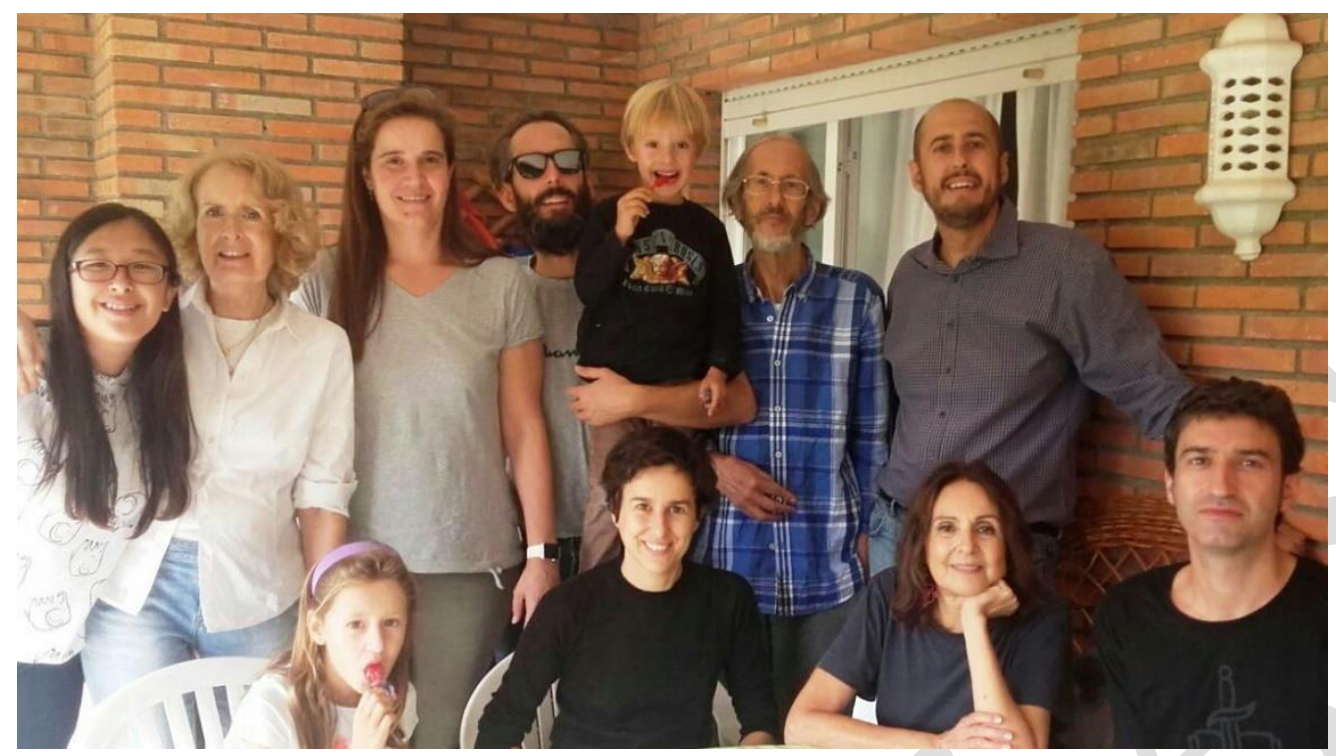

José Antonio Pérez Bowie con su familia en su casa de Salamanca, en la actualidad

A lo largo de su extensa trayectoria docente en la Universidad de Salamanca, además de como profesor de las materias del área - Crítica literaria, Teoría de la literatura, Literatura comparada, Literatura y cine, Teoría del lenguaje literario, etc. - en las diferentes titulaciones de Filología de la Facultad, en las que se hizo acreedor al respeto y la simpatía de sus alumnos, participó con mucha frecuencia en programas de cursos internacionales, impartiendo contenidos relacionados con la literatura, el cine o la cultura española. También fue un muy activo organizador de actividades científicas, seminarios, cursos de verano, congresos y conferencias, que dinamizaron la vida cultural y universitaria de la ciudad. Así como hizo lo propio desde los puestos de gestión universitaria que desempeñó, como Vicedecano o como Subdirector del Colegio Universitario de Zamora -primera piedra del campus salmantino hoy floreciente en la ciudad, que él contribuyó decisivamente a poner en marcha en los años noventa-. De manera recíproca, siempre dispuesto generosamente a participar allí donde ha sido llamado, su presencia en reuniones científicas, conferencias, tribunales, etc. le han convertido en un viajero incansable por todo el mundo, dejando dondequiera que vaya la impronta de su elocuencia, su buen humor y su gusto por la conversación, tan legendarios entre amigos y anfitriones como su frugalidad en la comida.

En su faceta como investigador y ensayista, lejos de mantener su posición referencial en un único ámbito de conocimiento y de permanecer, cómo ahora se dice, en una «zona de confort» que le permitiera rentabilizar sus trabajos, José Antonio Pérez Bowie ha mostrado a lo largo de su trayectoria un espíritu inquieto, una inteligente lucidez y un continuo deseo de seguir aprendiendo que le ha llevado a desarrollar diversas líneas de investigación vinculadas con las distintas áreas de conocimiento de la Literatura española, la Teoría de la literatura y la Literatura comparada que jalonaron su formación y su actividad profesional. Por ceñirnos tan solo a sus principales libros —escritos individual o colectivamente-, desde sus tempranas investigaciones sobre El léxico de la muerte en la literatura de la Guerra Civil -resultado de su tesis doctoral, dirigida por Eugenio de Bustos (Pérez Bowie, 
1982b) - o sobre El exilio cultural de la guerra civil (1996b) hasta sus últimas publicaciones sobre las Ficciones Nómadas (2017a) hay todo un recorrido que pone de manifiesto un dinamismo, una mutabilidad y una mirada liberada de prejuicios sobre el conocimiento, así como unas envidiables ética y capacidad de trabajo que aúnan tesón y talento. El historiador y teórico de la literatura ha navegado por los principales archigéneros - la lírica, el ensayo, la narrativa y, de manera muy especial, el teatro (Pérez Bowie 1996c, 2004b, 2006a)—. El crítico literario ha editado, antologado y escrito sobre la obra de autores como Mariano José de Larra (1987a), Pío Baroja (1990a), Luis de Oteiza (1993a), Juan Ramón Jiménez (1994c), Estébanez Calderón (1995a), mostrando una especial predilección por las de Gonzalo Torrente Ballester (2006a) o Max Aub (1985a, 1999e, 2001a). El comparatista ha dirigido su mirada a la recepción del cine en España en Materiales para un sueño (1996e), la teoría cinematográfica en Leer el cine (2008a) o la teoría y la práctica de la adaptación en La adaptación de textos literarios (2003g), cuestiones que ha venido aplicando sistemáticamente a sus análisis sobre la historia del cine español durante la dictadura franquista a través de Cine, literatura y poder (2004a), El mercado vigilado (2010a) y La noche se mueve (2013a).

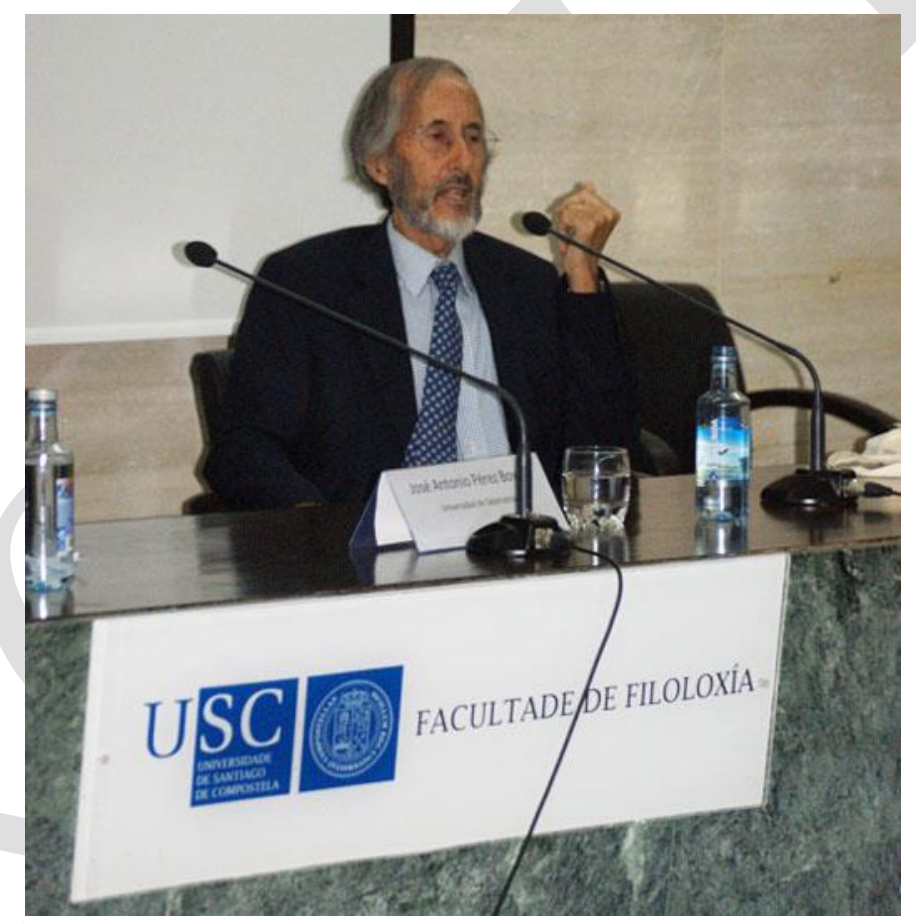

José Antonio Pérez Bowie, impartiendo una conferencia en el XX Simposio de la Sociedad Española de Literatura General y Comparada (SELGYC), celebrado en la Universidade de Santiago de Compostela en septiembre de 2014.

En esta línea filmoliteraria que ha ocupado su trayectoria más reciente merecen sin duda ser destacados, por su valor pionero en el comparatismo hispánico y, sobre todo, por la condición referencial que con el tiempo han ido adquiriendo, sus trabajos dedicados a la teoría de la «adaptación literaria» y a su desbordamiento por los conceptos de reescritura, transescritura y transmedialidad. En este sentido, Reescrituras filmicas (2010b) ha supuesto el punto de inflexión que ha establecido que cualquier acercamiento teórico al estudio de los trasvases al medio fílmico ha de partir de la visión de 
conjunto sobre el haz completo de las relaciones intermediales, trascendiendo también la tradicional centralidad otorgada a la literatura en este sistema adaptativo. Desde esta atalaya, el profesor Pérez Bowie ha dirigido al cine una mirada privilegiada y liberada, producto de la consiguiente consideración de las películas basadas en un texto literario en cuanto procesos reescriturales susceptibles de ser analizados de forma independiente y autónoma, no como meras transformaciones argumentales de una obra previa, tal y como puede observarse en Transescrituras audiovisuales (2015a), iniciador de una línea que se extiende por el monográfico Transmedialidad y nuevas tecnologías (2015b) y por la ya citada - y última publicación de su extensa bibliografía hasta el momento- Ficciones nómadas (2017a); a la postre, junto con Reescrituras fílmicas, los cuatro volúmenes colectivos constituyen el corpus principal de los trabajos del Grupo de Estudios sobre Literatura y Cine (GELYC) que ha dirigido desde su constitución en la Universidad de Salamanca.

En el conjunto de estos trabajos y proyectos de investigación de los que derivan, podrá encontrarse la misma mirada fresca, lúcida y liberada de ideas preconcebidas que caracteriza su acercamiento a los estudios filmoliterarios — que parte, además, de un profundo conocimiento y asimilación de los principales hitos universales que marcan el estado de la cuestión teórica- y que puede detectarse tanto en lo transdisciplinar de sus enfoques como en la curiosidad intelectual que le han llevado a ampliar el foco en dirección a los territorios del cómic, los videojuegos o los nuevos medios y narrativas de la era digital. Su diversidad de intereses, unida a una visión del conocimiento en la que no hay cabida para los prejuicios, está también en la base de su oceánica, irónica y heterogénea sabiduría, que le lleva a pasar del recitado de un poeta latino al comentario de una letra de una canción de Def con Dos, cultivando con el conocimiento del botánico y la destreza del jardinero —que E. Coseriu requería para el estudio de las ciencias del lenguaje- un espacio crítico «todoterreno» que podía abarcar en un momento dado desde la lírica del rock and roll al análisis narratológico de los anuncios de sexo en la prensa como género particular de microrrelatos.

Homenajeando a esa pluralidad y, por qué no, incluso eclecticismo de sus objetivos, métodos, campos y objetos de estudio, este monográfico incluye aportaciones de colegas procedentes de diversas áreas de conocimiento. Como no podía ser de otra forma, son mayoría los que pertenecen a la de Teoría de la literatura y literatura Comparada, pero también hay entre quienes han querido sumarse al homenaje al profesor Pérez Bowie docentes e investigadores que trabajan en cuestiones de Literatura española, Comunicación audiovisual o Historia del cine. Tal interdisciplinariedad se dejan notar en la estructura a través de las que se han ordenado los artículos, repartidos en tres bloques — «Teoría de la literatura», «Literaturas hispánicas»y «Estudios filmoliterarios, intermediales e interartísticos»—que, grosso modo, coinciden con las principales líneas de investigación desarrolladas por el homenajeado. También son diversas las instituciones de procedencia de los autores, que representan a buena parte de las universidades españolas y no pocas extranjeras, demostrando con ello las excelentes relaciones e iniciativas de colaboración internacional que el profesor siempre ha mantenido con colegas de otros departamentos o universidades, y la magnífica consideración personal y profesional de la que ha gozado en el ámbito académico del hispanismo... «y más allá». 
Como coordinadores del volumen, sirvan estas últimas líneas para trasladar nuestro agradecimiento a los autores de todas y cada una de las colaboraciones, que respondieron al encargo reservado y apremiante de participar en la publicación con entusiasmo y amabilidad, en medio de un ya habitualmente interminable y sobrecargado de tareas final de curso al que los sucesivos planes de estudio parecen condenarnos; a quienes no pudieron sumarse al volumen con una contribución pero han querido sumarse al homenaje desde la Tabula Gratulatoria; y a todo el equipo de Tropelías, y de forma muy especial a Túa Blesa por la iniciativa con la que originó e impulsó el proyecto y la generosidad con la que, junto a Juan Carlos Pueo, ofreció las páginas de esta revista para acogerlo, así como por todo el esfuerzo invertido por el equipo de la revista en las tareas de edición y maquetación, así como a José Seoane por su impagable ayuda en la compilación del listado bibliográfico. Y, por encima de todo, sirvan también para, como discípulos honrados que nos sentimos del profesor Pérez Bowie - con quien, desde que dirigió nuestras respectivas tesis doctorales, hemos colaborado en numerosos proyectos y hemos mantenido una relación de afecto y amistad que trasciende con mucho lo meramente profesional-, mostrar nuestra admiración y gratitud hacia quien se ha convertido además de en un referente humano y académico indispensable, en el maestro tranquilo del que sentirnos siempre orgullosos. 


\section{Bibliografía (seleccionada) de José Antonio Pérez Bowie}

(2017a) y Gil González, A. J. (eds.): Ficciones nómadas. Procesos de intermedialidad literaria y audiovisual. Madrid, Pigmalión.

(2017b): «Los hipotextos del biopic». En Pérez Bowie, J. A. y Gil González, A. J. (eds.) Ficciones nómadas. Procesos de intermedialidad literaria y audiovisual. Madrid, Pigmalión, pp. 273-313.

(2016a): «El género biográfico en el cine: a propósito de Mishima. A life in four chapters (Paul Schrader, 1985)». En Bouso González, S., Couto-Cantero, P., Núñez Ramos, R. y Paz Gago, J. M. (eds.), La pantalla ficticia: literatura y tecnologías de la comunicación. Madrid, Pigmalión, pp. 165-198.

(2016b): «Notes on the cinematographic canon and its relation to the theory of genres in a Spanish and Portuguese context». En Domínguez, C., Abuín, A. y Sapega, E. (eds.), A Comparative History of Literatures in the Iberian Peninsula, vol. II. Boston, John Benjamin Publishing, pp. 531-549.

(2015a) y Pedro Javier Pardo (eds.): Transescrituras audiovisuales. Madrid, Pigmalion.

(2015b) y Javier Sánchez Zapatero (eds.): Transmedialidad y nuevas tecnologías. Monográfico de la revista 1616. Anuario de la Sociedad Española de Literatura General y Comparada, 5.

(2015a): «La revista Objetivo en el panorama cinematográfico español: el realismo como resistencia». En Larraz, F. (ed.), Estudios de literatura, cultura e historia contemporánea en homenaje a Francisco Caudet. Madrid, Servicio de Publicaciones de la Universidad Autónoma de Madrid, pp. 485-504.

(2015b): «En torno a la biografía fílmica. Una propuesta de tipología». En Pérez Bowie, J. A. y Pardo García, P. J. (eds.), Transescrituras audiovisuales. Madrid, Pigmalion, pp. 19-46.

(2015c): «La autobiografía en pantalla: aproximaciones a un formato cinematográfico». En Hernando Cuadrado, L. A. y Sánchez Lobato, J. (eds.), Lengua y discurso. Madrid: Visor, pp. 255-287.

(2015d): «¿Existe un equivalente cinematográfico de la novela lírica? Notas sobre la "narración mitigada" en la pantalla». ALEC, 40, Extra 1, pp. 285-313.

(2015e): «Algunas notas más sobre la poética teatral de Max Aub. Referencias a la escena en "Nuevos diarios inéditos” (1939-1972)». El Correo de Euclides: anuario científico de la Fundación Max Aub, 10, 103-112.

(2015f): «Reciclado frente a adaptación. El tratamiento de materiales literarios y fílmicos en Oviedo exprés (Gonzalo Suárez, 2007)». España contemporánea: Revista de literatura y cultura, 24-25, 2-1, pp. 147-160.

(2014a): «Lecturas cinematográficas del siglo XIX español». En Hueso Montón, A. L. y Camarero Gómez, M. G. (coords.), Hacer historia con imágenes. Madrid, Síntesis, pp. 149-166.

(2014b): «El género biográfico en la pantalla. Una aproximación a su tratamiento en el cine español». En López Criado, F. (ed.), Literatura, cine y prensa: el canon y su circunstancia. Santiago de Compostela, Andavira, pp. 447-458. 


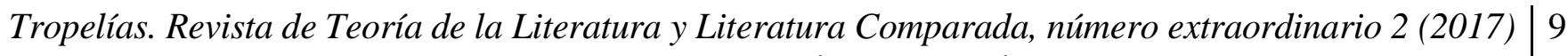
José Antonio Pérez Bowie: el profesor tranquilo

(2013) (ed.): La noche se mueve. La adaptación en el cine del tardofranquismo. Madrid, Ediciones Catarata, $317 \mathrm{pp}$.

(2013b): «El discurso teórico en torno a la adaptación cinematográfica durante el tardofranquismo».

En Pérez Bowie, J. A. (ed.), La adaptación en el cine del tardofranquismo. Madrid, Ediciones Catarata, pp. 13-93.

(2013c): «Jorge Amado reescrito en la pantalla: La adaptación de Tieta do Agreste (Carlos Diegues, 1986)». En Rivas Hernández, A. (ed.), Jorge Amado: Relectura en su centenario. Salamanca, Centro de Estudios Brasileños, pp. 241-257.

(2013d): «Come filmare i clasici del teatro. Appunti sulla recezione critica degli adattamenti shakespeariani in Spagna (1960-1970)». En D’Amico, M. (ed.): Oltre la pagina: il testo letterario e le sue metamorfosi nell'era dell'imagine. Roma, Edizioni di Storia e Letteratura, pp. 219-238.

(2013e): «La presencia de la instancia narradora en el relato cinematográfico». En Álvarez, M. (ed.), Imágenes conscientes. AutoRepresentaciones. Francia, Éditions Orbis Tertius, pp. 47-71.

(2013f): «Estrategias metaficcionales en la pantalla: su función lúdica». En Gutiérrez Carbajo, F. (coord.). Relato audiovisual y humor. Madrid, UNED, pp. 57 - 73.

(2013g): «The Literature of Valle-Inclán Transposed to the Screen: a Problematic Rewriting». Forum for World Literary Studies, vol 5, nº 1, april, pp. 94-121.

(2013h): «Reescritura cinematográfica y deslegitimación del discurso dominante. Dos adaptaciones de Valle-Inclán en el cine del franquismo». Krypton, 2, pp. 61-75.

(2013i): «La poética teatral de Max Aub. Los escritos sobre teatro en la prensa mexicana (II)». El Correo de Euclides: anuario científico de la Fundación Max Aub, 8, pp. 100-109.

(2012a) (ed.): «Gonzalo torrente Ballester y el teatro». Monográfico de la revista La Tabla Redonda, $\mathrm{n}^{\mathrm{o}} 10$.

(2012b): «En torno a El pavoroso caso del Señor Cualquiera. Antecedentes y función de la ficción enmarcada». La Tabla Redonda. 10, pp. 33 - 56.

(2012c): «Literatura y cine. Perspectivas de investigación comparatista». En Aullón de Haro, P. (ed.), Metodologías comparatistas y Literatura comparada. Madrid, Dykinson, pp. 427-440.

(2012d): «Metaficción cinematográfica. Algunas notas más sobre la cuestión». En Álvarez, M., Gil, A. y Kunz, M. (eds.), (Meta)Narrativas hispánicas. Alemania, Lit Verlag, pp. 25-42.

(2012e): «El teatro de Jacinto Benavente en el cine: Tres adaptaciones y sus contextos». Hecho Teatral, 12, pp. 85-115.

(2012f): «León Felipe frente a los discursos históricos y a sus fabulaciones». Laberintos: revista de estudios sobre los exilios culturales españoles, 14, pp. 226-234.

(2012g): «La poética teatral de Max Aub. Los escritos sobre teatro en la prensa mexicana». El Correo de Euclides: anuario científico de la Fundación Max Aub, 7, pp. 146-156.

(2011a) y Carmen Becerra Suárez (eds.): Mujeres escritas. El universo femenino en la obra de Torrente Ballester. Madrid, CSIC y Ediciones Catarata, 302 pp. 
10 Tropelías. Revista de Teoría de la Literatura y Literatura Comparada, número extraordinario 2 (2017) Antonio J. Gil González y Javier Sánchez Zapatero

(2011b): «Torrente Ballester ante algunas heroínas del teatro contemporáneo. Tipos y estereotipos femeninos en sus textos de teoría y crítica teatrales». En Becerra Suárez, C. y Pérez Bowie, J. A. (eds.) Mujeres escritas. El universo femenino en la obra de Torrente Ballester. Madrid, CSIC y Ediciones Catarata, pp. 185 - 204.

(2011c): «Carlos Marzal: Relato del viajero ocasional». En Cano Ballesta (ed.), Die Spanische Lyrik der Gegenwart (1980-2005). Alemania, Iberoamericana Vervuert, pp. 287-300.

(2011d): «Las determinaciones genéricas en los procesos adaptativos». Arbor, 748, pp. 305-315.

(2011e): «En torno a la comunicación teatral. Notas sobre pragmática del discurso secundario». Boletín Biblioteca Menéndez Pelayo, LXXXVII, pp. 337-348.

(2011f): «El seudodocumental como instrumento de revisión de la historia. Notas sobre El grito del sur, de Basilio Martín Patino». En Porro Herrera, M. J. y Sánchez Dueñas, B. (eds.), El exilio literario andaluz de 1939. Córdoba, Universidad de Córdoba, pp. 69-86.

(2011g): «Gonzalo Torrente Ballester en Primer Acto. La maduración de una poética teatral». En Becerra, C. (ed.), Miradas sobre Gonzalo Torrente Ballester en su centenario (1910-2010). Vigo, Academia del Hispanismo, pp. 215-227.

(2011h): «Max Aub: El limpiabotas del Padre Eterno y otros cuentos ciertos; la mirada del narrador testigo». El Correo de Euclides: anuario científico de la Fundación Max Aub, 8, pp. 188-189.

(2010a) y Fernando González García: El mercado vigilado. La adaptación en el cine español de los 50. Murcia, Tres Fronteras, 456 pp.

(2010b) (ed.): Reescrituras fílmicas. Nuevos territorios de la adaptación. Salamanca, Ediciones Universidad de Salamanca, 363 pp.

(2010c): "Sobre escritura y nociones conexas: un estado de la cuestión». En Pérez Bowie, J. A. (ed.), Reescrituras fílmicas. Nuevos territorios de la adaptación. Salamanca, Ediciones Universidad de Salamanca, pp. 21-43.

(2010d): «El cine ante el teatro: Estrategias des-realizadoras y problematización de la escritura». En Torregrosa Puig, M. (ed.), Imaginar la Realidad. Ensayos sobre la representación de la realidad en el cine, la televisión y los nuevos medios. Sevilla, Comunicación Social, pp. 91-110.

(2010e): «Gonzalo Torrente Ballester, crítico teatral: la recepción del teatro europeo y norteamericano contemporáneo». Cuadernos del Lazarillo, 38-39, pp. 17-25.

(2010f): «La figura del exiliado en el cine franquista». En Cabañas Bravo, M. (ed.), Analogías en el arte, la literatura y el pensamiento del exilio español de 1939. Madrid, CSIC, pp. 107-117.

(2010g): «La teatralidad en la pantalla. Un ensayo de tipología». SIGNA, 19, pp. 35-62.

(2010h): «¿Transgredir es seducir? En torno a España, novela de Manuel Vilas». En Merlo, P. (ed.), Manipuler. Séduire. Le createur et sa critique 2. (Francia), Presses Université de Saint Etienne, pp. 101-109.

(2009a) y Salvador Crespo Matellán, María Luisa García Nieto, Manuel González de Ávila, Ma José Rodríguez Sánchez de León y Ascensión Rivas Hernández (eds.): Teoría y análisis de los 
discursos literarios. Estudios en homenaje al profesor Ricardo Senabre Sempere. Salamanca, Ediciones Universidad de Salamanca, 566 pp.

(2009b): «José Miguel Ullán o el grado cero de la escritura». En VVAA (eds.), Teoría y análisis de los discursos literarios. Estudios en homenaje al profesor Ricardo Senabre Sempere. Salamanca, Ediciones Universidad de Salamanca, pp. 281-294.

(2009c): «La novela de Pío Baroja en el cine». Ínsula. Revista de letras y ciencias humanas, 719, pp. 33-36.

(2009d): «Sobre consumo teatral: algunas notas a la cartelera madrileña reciente». Las puertas del drama: revista de la Asociación de Autores del Teatro, 35, pp. 9-14.

(2009e): «En torno a la narratividad teatral. Las relaciones cine-teatro en el discurso teórico de Gonzalo Torrente Ballester». Tropelías. Revista de Teoría de la Literatura y Literatura Comparada, $\mathrm{N}^{\circ}$ dedicado al III Seminario Pensamiento literario español del siglo XX, 3, pp. 113 - 124.

(2009f): Gonzalo Torrente Ballester: Escritos de teoría y crítica teatral. Vigo, Editorial Academia del Hispanismo.

(2009g): «Hacia un nuevo concepto de la teatralidad cinematográfica. Notas sobre la recepción de las teorías de André Bazin en España (1950-1961)». Lecturas: Imágenes. Revista de Poética de la Imagen, 6, pp. 47-68.

(2008a): Leer el cine. La teoría literaria en la teoría cinematográfica. Salamanca, Universidad, 216 pp.

(2008b): «La adaptación como reescritura. Algunos ejemplos de la filmografía de Vicente Aranda». En Notario Ruiz, A. y Molinuevo, J. L. (eds.), Estética: Perspectivas contemporáneas. Salamanca, Ediciones Universidad de Salamanca, pp. 67-88.

(2008c): «La dimensión ensayística de la narrativa aubiana». El Correo de Euclides, 3, pp. 81-89.

(2007a) y Manuel González de Ávila y Fernando González García: Interculturalidad, literatura y cine. Barcelona: Anthropos.

(2007b) y Fernando González García: «La pantalla postcolonial en el África subsahariana. Hyènes, de Mambety, una excepción paradigmática». Revista Anthropos, 216, pp. 91-101

(2007c): «Alfonso Sastre en el cine. La versión fílmica de La cornada (A las cinco de la tarde, de Juan Antonio Bardem)». República de las Letras, 101, pp. 98-112.

(2007d): «Notas sobre las categorías de espacio teatral y espacio cinematográfico». Las puertas del drama: revista de la Asociación de Autores del Teatro, 30, pp. 22-27

(2007e): «La función paródica de las estrategias metaficcionales: apuntes sobre la versión cinematográfica de la zarzuela Doña Francisquita, de Ladislao Vajda. Anales de Literatura Española, 19, pp. 189-204.

(2006a): La poética teatral de Gonzalo Torrente Ballester. Pontevedra, Mirabel Editorial. 
12 Tropelías. Revista de Teoría de la Literatura y Literatura Comparada, número extraordinario 2 (2017) Antonio J. Gil González y Javier Sánchez Zapatero

(2006b): «El cine negro y la teoría de los géneros». En Martín Escribà, A. y Sánchez Zapatero, J. (eds.), Manuscrito criminal. Reflexiones sobre novela y cine negro. Salamanca: Cervantes, pp. 179-89.

(2006c): «En torno a la concepción aubiana del realismo». El Correo de Euclides: anuario científico de la Fundación Max Aub, 1, pp. 486-496.

(2006d): «La novela de Pío Barona en el cine». Ínsula: revista de letras y ciencias humanas, 719, pp. 33-36.

(2005a): «La ficcionalización del discurso ensayístico. Sobre "Homenaje a Lázaro Valdés” de Max Aub». En Rojo, G. y Valender, J. (eds.), Homenaje a Max Aub. México D.F.: Colegio de México, pp. 127-141.

(2005b): «Max Aub y la cultura francesa». En Ette, O., Figueras, M. y Jurt, J. (eds.), Max Aub-André Malraux: guerra civil, exilio y literatura. Madrid/Frankfurt: Iberoamericana/Vervuert, pp. 109124.

(2005c): «Fernando Lázaro, dramaturgo: el estreno de "La señal”». En Santos Río, Luis (coord.), Palabra, norma, discurso: en memoria de Fernando Lázaro Carreter. Salamanca, Ediciones Universidad de Salamanca, pp. 897-906.

(2005d): «Las servidumbres naturalistas del cine (sobre algunas adaptaciones cinematográficas recientes de textos teatrales "problemáticos")». En Vilches de Frutos, M. F. y Floeck, W. (eds.), Teatro y sociedad en la España actual. Madrid/Frankfurt: Iberoamericana/Vervuert pp. 283-302. (2005e): «El teatro en el cine mudo: análisis de dos ejemplos de la producción española». Anales de Literatura Española, ALEC, 30 (1-2), pp. 395-432.

(2005f): «La modernidad de la narrativa breve del exilio». Quimera: Revista de Literatura, 252, pp. 21-25.

(2005g): «El cine en, desde y sobre el cine: metaficción, reflexividad e intertextualidad en la pantalla». Anthropos, 208, pp. 122-137.

(2004a): Cine, literatura y poder. La adaptación cinematográfica durante el primer franquismo. Salamanca, Librería Cervantes.

(2004b): Realismo teatral y realismo cinematográfico. Las claves de un debate (España 1910-1936). Madrid, Biblioteca Nueva.

(2004c): «Teatro y cine: un permanente diálogo intermedial». Árbor, 699-799, pp. 573-594.

(2004d): «La adaptación cinematográfica a la luz de algunas aportaciones teóricas recientes». Signa. Revista de la Asociación Española de Semiótica, 13, pp. 277-300.

(2003a): «El canon narrativo aubiano». Ínsula. Revista de letras y ciencias humanas, 678, pp. 22-27. (2003b): «Sobre el compromiso de Max Aub: La literatura como rebelión y como revelación». Revista de Occidente, 265, pp. 39-55.

(2003c): «El cine poético como opción vanguardista en España». Litoral, 235, pp. 144-156. 
(2003d): «En torno a la lengua literaria de Max Aub: entre experimentación y compromiso». En Senabre, R., Rivas Hernández, A. y Gabaráin, I. (eds.), El lenguaje de la literatura (1898-1936). Salamanca, Ambos Mundos, pp. 105-123.

(2003e): «Las ideas teatrales de 1900 a 1939». En Huerta Calvo, J. (ed.), Historia del Teatro Español. Madrid, Gredos, pp. 2259-2270.

(2003f): «Las esquinas del aire o las permeables fronteras de la ficción». En López de Abadía, J. M. (ed.), Juan Manuel de Prada: De héroes y tempestades. Madrid, Verbum, pp. 358-383.

(2003g) (ed.): La adaptación cinematográfica de textos literarios. Teoría y práctica. Salamanca, Plaza Universitaria Ediciones, $173 \mathrm{pp}$.

(2003h): «La teoría sobre la adaptación cinematográfica de textos: estado de la cuestión». En Pérez

Bowie, J. A. (ed.), La adaptación cinematográfica de textos literarios. Teoría y práctica. Salamanca, Plaza Universitaria Ediciones, pp. 11-30.

(2003i): «La saga/fuga de J.B. Crónica de una recepción». La Tabla Redonda, 1, pp. 101- 127.

(2003j) y Antonio J. Gil González, Ángel Basanta y José Antonio Ponte Far: «La tabla redonda de la crítica». La Tabla Redonda, 1, pp. 209-228.

(2003k): «La lírica como transgresión en la España de fin de siglo. Apuntes sobre el rock marginal».

En Aymes, J. R. (ed.), Les fins de siècles en Espagne. Francia, Presses de la Sorbonne-Nouvelle, pp. 249-273.

(20031): «Noticias y reflexiones sobre la adaptación cinematográfica de textos teatrales en algunos escritos autobiográficos (Escobar, Fernán-Gómez, Bardem, Sáenz de Heredia)». En Romera Castillo, J. (ed.), Teatro y memoria en la segunda mitad del siglo XX. Madrid, Visor Libros, pp. 171-186.

(2003m): «Rafael Alberti y el cine: textos y contexto». En Díez de Revenga, J. y de Paco, M. (eds.), Aire del sur buscado. Estudios sobre Luis Cernuda y Rafael Alberti. Murcia, Caja Murcia, pp. 293-313.

(2002a): «Los contextos de la adaptación. Dos lecturas cinematográficas de un texto teatral de Manuel y Antonio Machado». En Romera Castillo, J. (ed.), Del teatro al cine y la televisión en la segunda mitad del siglo XX. Madrid, Visor Libros, pp 463-476.

(2002b): «Literatura y propaganda». En el catálogo de la exposición Propaganda en guerra. Salamanca, Consorcio de Salamanca, pp. 31-49.

(2001a): Campo abierto. Valencia, Diputación Provincial de Valencia.

(2001b): «El cine en el debate ideológico. La recepción de las cinematografías soviética y nazi». En Saverio Festa, F., Grillo, R. M. y Pellicani, A. (eds.), La Spagna degli anni 30 di fronte alle'Europa. Italia, Convegno di Salerno, pp. 373 - 394.

(2001c): «La poética antirrealista». En Becerra, C. (ed.), Lecturas-Imágenes. Vigo, Universidade de Vigo, pp. 103-122. 
14 Tropelías. Revista de Teoría de la Literatura y Literatura Comparada, número extraordinario 2 (2017) Antonio J. Gil González y Javier Sánchez Zapatero

(2001d): «Cómo se vende el sexo (La dimensión ficcional de los mensajes de relax del diario El País)». En Bartol Hernández, J. A. (ed.), Nuevas aportaciones al estudio de la lengua española. Salamanca, Luso-Española de Ediciones, pp. 435-443.

(2001e): «La ficción como documento. Dos ejemplos de la narrativa reciente». En Fariña Busto, M. J.

y Troncoso Durán, M. D. (eds.), Sobre literatura fantástica. Homenaxe ó profesor Antón Risco. Vigo, Universidade de Vigo, pp. 213-227.

(2001f): «Teatro en verso y cine. Una relación conflictiva». Anales de Literatura Española, ALEC, 26 (1), pp. 317-335.

(2001g): «Cine y vanguardia». Lecturas, imágenes: revista de poética de cine, 1, pp. 103-122.

(2000): «La modernidad de la narrativa aubiana. Propuesta para una relectura». En Homenaje a José $M^{a}$ Martínez Cachero. Vol. III. Oviedo, Universidad de Oviedo, pp. 311-321.

(1999a): «Semioestilística del compromiso. Una nueva mirada sobre la poesía de la guerra civil española». Ínsula. Revista de letras y ciencias humanas, 636.

(1999b): «La historia como ficción en Las máscaras del héroe de Juan Manuel de Prada». España contemporánea: revista de literatura y cultura, 11 (2), pp. 61-72.

(1999c): «El TEU salmantino: treinta años de actividad teatral universitaria (1940-1969)». En García Lorenzo, L. (ed.), Aproximación al teatro español universitario (TEU). Madrid, CSIC, pp. 139171.

(1999d): «Dos reflexiones cinematográficas sobre el exilio: El ángel exterminador, de Buñuel y La guerra ha terminado, de Resnais-Semprún». La Nueva Literatura Hispanica, 3, pp. 155-172.

(1999e): Manuscrito Cuervo. Historia de Jacobo. Madrid, Universidad de Alcalá.

(1999f): «Max Aub: la escritura en subversión». En Fernández Martínez, D. y Soldevila Durante, I. (eds.), Max Aub: veinticinco años después. Madrid, Editorial Complutense, pp. 209-223.

(1999g): «Dimensión ficcional y dimensión metaficcional del texto secundario (Sobre el último teatro de Alfonso Sastre)». En Ascunce, J. Á. (ed.), Once ensayos en busca de un autor: Alfonso Sastre. Hondarribia, Editorial Hiru.

(1999h): «El cuestionamiento de la noción de realismo teatral a partir de la aparición del cine». En Martínez Fernández, J. E. (ed.), Trilcedumbre. Homenaje al profesor Francisco Martínez García. León, Universidad de León, pp. 417-427.

(1998a): «La modernidad canonizada: las generaciones de fin del siglo en la colección Austral». Ínsula. Revista de letras y ciencias humanas, 622.

(1998b): «Sobre los poemas con personaje histórico analógico en la lírica española contemporánea». En Biografías Literarias. Lírica y biografía, pp. 593-608. Madrid, Visor Libros.

(1998c): «La memoria como supervivencia en Max Aub. Una lectura de El remate». Turia, 43-44, pp. 169-181.

(1998d): «Greta Garbo y las vanguardias». En Navarro González, A., Pueo Domínguez, J. C., Saldaña Sagredo, A., Blesa, J. Á. (eds.), Mitos. Actas del VII Congreso Internacional de la Asociación Española de Semiótica, pp. 188-199. 
(1998e): «La recepción del cine en la práctica teatral de Muñoz Seca». En Romero Ferrer, A. y Cantos Casenave, M. (eds.), Pedro Muñoz Seca y el teatro de humor contemporáneo (1898-1936). Cádiz, Universidad de Cádiz, pp. 1951-2088.

(1997): «Lírica y biografía (acerca de los poemas con personaje histórico analógico en la lírica española contemporánea)”. En Romera Castillo, J. N. y Gutiérrez Carbajo, F. (coords.), Biografías literarias (1975-1997) (Actas del V Seminario Internacional del Instituto de Semiótica Literaria y Teatral de la UNED). Madrid, Visor, pp. 593-608.

(1996a): «Max Aub: los límites de la ficción». En Alonso, C. (ed.), Actas del Congreso Internacional sobre Max Aub. Vol. I. Valencia, Ayuntamiento de Valencia, pp. 367-382.

(1996b) y José Ma Ballcels (eds.): El exilio cultural de la guerra civil (1936-1939). Salamanca, Universidad de Salamanca.

(1996c): La Novela Teatral. Madrid, CSIC.

(1996d): «La inviabilidad de la novela histórica: La saga de los Marx, de Juan Goytisolo». En Romera Castillo, J., García-Page Sánchez, M. (eds.), La novela histórica a finales del siglo XX, (Actas del V Seminario Internacional del Instituto de Semiótica Literaria y Teatral de la UNED). Madrid, Visor, pp. 337-349

(1996e): Materiales para un sueño. En torno a la recepción del cine en España (1896-1936). Salamanca, Librería Cervantes.

(1996f): «La ficción autobiográfica: Franco según Vázquez Montalbán». En Pozuelo Yvancos, J. M. y Vicente Gómez, F. (eds.), Mundos de ficción (Actas del VI Congreso Internacional de la Asociación Española de Semiótica). Murcia, Universidad de Murcia, pp. 1191-1197.

(1996g): «Desficcionalización versus desrealización en la narrativa de Max Aub». En Grillo, R. M. (ed.), La poetica del falso: Max Aub tra gioco ed impegno. Salerno (Italia), Edizione Scientifiche Italiane, pp. 81-96.

(1995a): Antología de Escenas andaluzas, de Estébanez Calderón, S. Madrid, CEGAL.

(1995b): «En torno al lenguaje poética fascista». En Rico, F. (coord.), Historia y crítica de la literatura española [Sánchez Vidal, A. (coord.), Vol. 7. Tomo 2. Época contemporánea: 1914-1939: primer suplemento]. Barcelona: Crítica, pp. 578-580.

(1994a): «El mito falangista del poeta soldado. Garcilaso personaje teatral en 1940». Cuadernos Interdisciplinarios de Estudios Literarios, Tomo 5, pp. 67-87.

(1994b): «La estructura de la acción dramática en Arniches. Análisis de Es mi hombre». En Ríos Carratalá, J. A. (ed.), Estudios sobre Carlos Arniches. Alicante, Instituto Juan Gil Albert, pp. 103-117.

(1994c): Minero de estrellas. Madrid, Fundación Juan Ramón Jiménez.

(1994d): «Sobre lírica y autorreferencialidad (Algunos ejemplos de la poesía española contemporánea)». En Fernández Roca, J. Á., Gómez Blanco, C. y Paz Gago, J. M. (eds.), Semiótica y modernidad, (Actas del V Congreso Internacional de la Asociación Española de Semiótica). A Coruña, Universidade da Coruña, pp. 237-247. 
16 Tropelías. Revista de Teoría de la Literatura y Literatura Comparada, número extraordinario 2 (2017) Antonio J. Gil González y Javier Sánchez Zapatero

(1993a) (ed.): El diablo blanco, de Luis de Oteyza. Badajoz, Diputación Provincial de Badajoz.

(1993b): «La ficcionalización del hablante dramático básico como recurso paródico en el teatro de humor de preguerra». Teatro siglo XX, pp. 287-300.

(1993c): «Pragmática de la lírica: la enunciación en primera persona ajena en la poesía funeraria y mitológica de los Siglos de Oro». En García Martín, M. (ed.), Estado actual de los estudios sobre el Siglo de Oro. Salamanca, Universidad de Salamanca.

(1993d): «Sobre pragmática del texto teatral: el hablante dramático básico en el teatro de Alfonso Sastre». En Bartol Hernández, J. A., Santiago Guervós, J. y García Santos, J. F. (eds.), Estudios filológicos en homenaje a Eugenio de Bustos Tovar. Salamanca, Universidad de Salamanca, pp. 733-748.

(1992a): «Literatura beligerante: La novela durante la II República». Ínsula. Revista de letras y ciencias humanas, 546.

(1992b): «Mecanismos de titulación en el teatro de humor de preguerra». En Dougherty, D. y Vilches de Frutos, M. F. (eds.), El teatro español entre tradición y vanguardia. Madrid, CSIC, pp. 3144.

(1992c): «Para una tipología de los procedimientos metaficcionales en la lírica contemporánea». Tropelías. Revista de Teoría de la Literatura y Literatura Comparada, 3, pp. 91-104.

(1991): «Falange y Romanticismo». En Dengler Gassin, R. (ed.), Estudios humanísticos en homenaje a Luis Cortés Vázquez. Salamanca, Universidad de Salamanca, pp. 627-641.

(1990a (ed.): El mundo es ansí, de Pío Baroja. Madrid, Espasa Calpe.

(1990b): «Géneros y perspectivismo en La velada en Benicarló». Ínsula. Revista de letras y ciencias humanas, 526.

(1990c): «Cine versus teatro: el impacto del cinematógrafo en la teoría teatral de preguerra». En Fernández Gutiérrez, J. M. y García Lara, F. (eds.), El escultor Julio Antonio. Ensayos de aproximación. Tarragona, Diputación de Tarragona, pp. 119-132.

(1990d): «La complejidad del esquema comunicativo lírico como refuerzo de la ficcionalización. Algunos ejemplos de la poesía española del Siglo de Oro». Investigaciones Semióticas III. Vol. II. Madrid, UNED, pp. 247-256.

(1988a): «Un homenaje a Ramón J. Sender» Ínsula. Revista de letras y ciencias humanas, 496.

(1988b): «Retoricismo y estereotipación, rasgos definidores de un discurso ideologizado: el discurso de la derecha durante la guerra civil española». En Aróstegui Sánchez, J. (ed.), Historia y memoria de la guerra civil. Valladolid, Junta de Castilla y León, pp. 353-373.

(1988c): «Una recepción crítica ideologizada: la crítica teatral del diario ABC durante la II República».

En Investigaciones Semióticas II. Oviedo, Universidad de Oviedo, pp. 317-334.

(1987a) (ed.): Antología Prosas de Navidad. Madrid, CEGAL.

(1987b): «La calumnia, de Félix Grande. Nota de lectura». Ínsula. Revista de letras y ciencias humanas, 493. 
(1987c): «La definitiva resurrección de Luis Rosales». Ínsula. Revista de letras y ciencias humanas, 492.

(1986): «La poesía en la prensa zamorana durante la guerra civil». Studia Zamorensia, VIII, pp. 337355.

(1985a) (ed.): La calle de Valverde, de Max Aub. Madrid, Cátedra.

(1985b): «En torno al lenguaje poético fascista: la metáfora de la guardia eterna». Letras de Deusto, 15, pp. 73-96.

(1985c): «Teoría literaria durante la guerra civil española: una aproximación». Studia Histórica Historia Contemporánea, III, pp. 155-169.

(1984): «La literatura española entre el vanguardismo y la rehumanización: La revista Isla (Cádiz1932-1936)». Archivo Hispalense, 206, pp. 63-94.

(1983): «De nuevo sobre José María Morón». Studia Zamorensia, IV, pp. 327-343.

(1982a): «Datos para una sociología de la actividad teatral en Zamora». Studia Zamorensia, III, pp. 191-243.

(1982b): El léxico de la muerte durante la guerra civil española. Salamanca, Universidad de Salamanca.

(1980a): «La colección dramática La Novela Teatral (1916-1925)». Segismundo, XII, pp. 274-325.

(1980b): «Militancia obrera y literatura: la obra novelística de Isidoro Acevedo». Studia Zamorensia, I, pp. 217-224.

(1979): «La temática minera en la novela española de los años 30». Studia Philologica Salmanticensia, II, pp. 197-217.

(1978a): «Aproximación a la figura y a la obra de un poeta olvidado: José María Morón (1898-1966)». Studia Philologica Salmanticensia, II, pp. 191-216.

(1978b): «Nacionalismo vasco y socialismo en una novela de Pedro de Basaldúa». Letras de Deusto, 8, pp. 203-210.

(1978c) (ed): Contraataque, de Ramón J. Sender. Madrid, Almar.

(1978d) y Julio Borrego Nieto y José J. Gómes Asensio: «Sobre el tú y el usted». Studia Philologica Salmanticensia, 2, pp. 53-70. 